\title{
EVALUATION BY THE CURRICULUM GRADUATES AND EMPLOYERS. CASE: ENGINEER WORKS AND SERVICES UNIVERSITY CENTER OF SOUTH COAST - UNIVERSITY OF GUADALAJARA
}

\author{
Claudia Leticia Preciado Ortiz, M.D.F. \\ Alfredo Castañeda Palomera, M.C.
}

University Center of South Coast - University of Guadalajara, Autlan de Navarro, Jalisco, Mexico

\begin{abstract}
This work is part of the experience of tracking graduates and curriculum evaluation, derived from an international accreditation process conducted by the European agency AQU Catalunya University Center South Coast (South Coast CU) at the University of Guadalajara. Because of this, we conducted a Follow-up Study, which included generic skills (PROFLEX, 2010) of graduates demanded from the labor market, complemented by the Study of Employers who evaluated the same competency. In this study, generic skills in graduates of Career Engineer Works and Services are analyzed, contrasting perceptions of graduates and employers. The methodology is described and a method for the comparative analysis is proposed, the results and their implications for curriculum design career competencies are discussed.
\end{abstract}

Keywords: Graduates, Employers, Skills, Curriculum Evaluation

\section{Introduction}

The opinion of employers is increasingly a priority for Higher Educational Institutions (HEI) with respect to aspects of graduate training demanded by firms (López F., \& Montañes G., 2003). Educationemployment relationship is determined by social and political structures in certain geographical areas, where the local and international market becomes one of the most important indicators that guide the demands on higher education. Thus Diaz Barriga (2000) notes that "the proper functioning of the education system is reflected in the timely preparation of its graduates, according to the requirements of each position in the labor market." 
At the University Center of South Coast the continuous improvement at curricular proposals is important to ensure the relevance of their careers with the regional and national labor market, as it carries out information about monitoring graduates and employers review to let you know the congruence between the skills that form in its educational programs and requirements of the productive sector. This work was taken as an example to study Engineering Works and Services in the University Center of South Coast.

\section{Methodology}

Follow-up studies of graduates emerged to analyze the relationship between educational spending and economic growth; and the links between education investment and the benefits of individuals. Many universities have incomplete studies of graduates. There are two projects funded by the European Commission who conducted general surveys in Europe: CHEERS (1998), funded by the Fourth Framework Programme of the EU; and REFLEX (2004), supported by the Sixth Framework Programme of the EU, which achieved international recognition (PROFLEX, 2010). Derived from this experience, the ALFA project with the name PROFLEX (2010), who conducted a survey of graduates in Latin American universities based on the European experience that was performed.

According PROFLEX, proper monitoring of university graduates induces managers to consider the following questions: Do we know the strengths and areas of improvement in the training of our graduates?. Do we know if their skills are what the market requires?. Finally, we know the work history of our graduates? (PROFLEX, 2010).

In 1998 the National Association of Universities and Institutions of Higher Education (NAUIHE) published the document Core Scheme for Graduates Studies, informing that graduate follow-up is a key strategy in improving the HEI, it also generates information to support the processes of evaluation and updating plans and programs of study and the design of the new educational offer (NAUIHE, 1998).

From an educational perspective, employers' opinion surveys are a tool to gather information on the productive sector skills required by graduates to join the workplace efficient manner; based on that you can make decisions on the design of strategies for teaching and learning, new curricula or restructure existing curricula.

In studies of the labor market for professionals the relationship between the labor market and the HEI is analyzed, since they act as intermediaries, or catalysts for the needs of buyers and sellers, and employment opportunities at a professional level (Navarro, 1998). With this studies, the University Center of South Coast hopes to contribute an 
improvement the relevance of their curriculum, and build better conditions for the employment of its graduates, providing them with job skills, knowledge, abilities, skills, values and other tools allowing a positive impact on their professional field.

To conduct this study universe graduates and employers in the Engineering Works and Services were taken. As a reference the collection of information was taken as a reference database for the Coordination of the race (CUCSUR, 2010), which met the same requirements of validity and reliability in composition for purposes of the study (Malhotra, 2007). The sampling technique used was not random due to the features presented by the sample and the type of convenience (Gutiérrez, 2005).

Regarding the design of the questionnaire the one established by the PROFLEX project (2010), was taken as a reference, which uses more than 150 questions, with a structure consisting of nine sections covering aspects; the training, transition of work, competence and satisfaction, among others. Concerning the requirement of reliability of the instrument the Cronbach's Alpha test was applied, resulting in a value of 0.740 , which confirmed the degree of relevance of the items included. Likert was used as the scale of measurement where a value or address and the interviewed indicates if the respondent agrees or disagree with the statement - (McMillan, JH \& Schumacher, S., 2005: 240).

Since the application of the questionnaire was performed in most cases by telephone, it was considered that respondents may have difficulty remembering the list of issues, or have limitations in answering the questionnaire. So they chose to handle items in closed form,-one which the subject chooses between predetermined answers - (McMillan, JH \& Schumacher, S., 2005: 135).

With respect to the concept of competence, Hartog (1992) defines them as aptitudes? Abilities and skills of graduates in higher education that increases their productivity from a multidimensional perspective. The multidimensional nature as a novel element in the current concept of competence stand out. The questionnaire asks PROFLEX graduates reflections on the skills they have and they need for their jobs and the contribution of universities to learning from them. For this study, the questionnaire for employers was designed based on the PROFLEX. To analyze the results the opinion surveys of graduates (GR) and employers (EM) only the two highest levels of capacity on the relevant competence were used; "alot" and "to a large extent". Both together were referred to as "High level".

Descriptive statistics were used in analyzing the data and methodologies as the categorization of the skills were implemented, and the weighting of the views of GR and EM. In these weighting methods, 
experiences from Gómez G., and Z. Mendoza Castañeda P. (2010) were used with some modifications. This is how it was defined that the value of weighting of the $\mathrm{RG}$ is $30 \%(\mathrm{RGw}=0.30)$ and the value of weighting of the $\mathrm{EM}$ is $70 \%(\mathrm{EMw}=0.70 \%)$. The methodology is summarized in Table 1 according to present suggestions by the results obtained in the analysis of the views of GR and EM, the weighting GRW and EMW, the Weighted Average (WA) in the percentage of opinion and the maximum time in years to perform the review, modification and curriculum changes (TIMAX).

Table 1. RG and EM scenarios opinion, weighting GRW and EMW, and suggestions for a draft revision, modification and curriculum transformation.

\begin{tabular}{|l|l|l|l|}
\hline $\begin{array}{l}\text { Competence } \\
\text { of the } \\
\text { corresponding } \\
\text { category }\end{array}$ & $\begin{array}{l}\text { WA percentage } \\
\text { of opinion GR } \\
\text { y EM } \\
\text { GRW=0.30; } \\
\text { EM=0.70 }\end{array}$ & Suggestions & TIMAX \\
\hline \multirow{2}{*}{$\begin{array}{l}\text { Competition } \\
1,2, . . \mathrm{n}\end{array}$} & $\mathbf{9 0 - 1 0 0}$ & $\begin{array}{l}\text { Refine details and be aware of disciplinary } \\
\text { and environmental changes }\end{array}$ & 3 \\
\cline { 2 - 4 } & $70-79$ & $\begin{array}{l}\text { Perform surface and moderate changes: } \\
\text { review and define the competencies } \\
\text { according to GR and EM }\end{array}$ & 2 \\
\cline { 2 - 4 } & $60-69$ & $\begin{array}{l}\text { Perform moderate to profound changes: } \\
\text { Emphasize the elements and relevance of } \\
\text { skills according to GR and EM }\end{array}$ & 1 \\
\cline { 2 - 5 } & $50-59$ & $\begin{array}{l}\text { Making major changes: extension and } \\
\text { depth competency }\end{array}$ & 0.75 \\
\cline { 2 - 5 } & $\begin{array}{l}\text { Contents very strong changes: } \\
\text { Restructuring the curriculum and } \\
\text { competencies }\end{array}$ & 0.75 \\
\hline $\begin{array}{l}\text { Category 1, 2, } \\
. . \mathrm{n}\end{array}$ & $<50$ & $\begin{array}{l}\text { Start a curricular transformation } \\
\text { considering the "non grata" antecedent }\end{array}$ & 0.5 \\
\hline
\end{tabular}

The suggestion of what? and the time to do them, will depend on the weighted average for the relevant competition.

\section{Results}

The relevance of the educational program of the University Center of South Coast is based on the curriculum content thereof. One challenge is the ongoing evaluation of the impact of academic processes in society. This is important for developing strategies that lead to feedback of the educational programs curriculum that we already have and identify new training needs, in order to respond in a positive and innovative way to social needs; ie, providing better training to meet the open economy imposed by national and international competition, both professional services and like goods and services. 
The analysis proposed by poll is according to the six categories in which the capabilities of graduates are grouped according to the work required at the graduate level and profile cluster level. Subsequent to this, is the analysis of specific skills.

\section{Knowledge, analytical thinking, reasoning and tools}

This category refers to the capabilities of: mathematical logical reasoning; analytical thinking; to master knowledge of their areas or other areas; to acquire new knowledge quickly and use tools. These capabilities allow the individual to work with some intellectual criteria such as clarity, accuracy, precision, relevance, depth, breadth, logic, important significance and impartiality?

\section{Capacity logical mathematical reasoning}

$40 \%$ of GR have mentioned that they count with a high level relative to the competence; and $50 \%$ said that the company where they work requires a high level in this competence? That is, the GR perceived themselves with less mathematical logical reasoning, than what they believe the businesses require.

Moreover $10 \%$ of the EM mentioned that GR working in their organizations have high-level logical mathematical reasoning (Table 10).

\section{Ability of analytical thinking}

$20 \%$ of GR indicated that critical thinking ability is high; and regarding the companies in which 50\% work said that they require high-level professionals who have this ability. That is, the GR perceived themselves with less analytical thinking, that what they believes that businesses require. Turning to the views of EM, $50 \%$ of them felt that their institutions require professionals with this high level of competence, as well as the same percentage of EM mentioned that GR working in their organizations have a high level. That is, both the EM and GR perceive that the EG have this capability in high level (Table 2).

\section{Ability to master knowledge of your area}

In this competence both the EG and EM revealed that they account a high level therefore? Agree with the review of performance of the GR that $50 \%$ is what the businesses require; and in the same way $50 \%$ of the EM believe that their institution need professionals with this high level of competence and they also coincide with the percentage of MS, who feel that graduates working in their companies have this competence in the required level (Table 2). 


\section{Ability to master knowledge of other areas}

$40 \%$ of GR mentioned that they have less of this competence than what companies require; and $50 \%$ of EM believe that their institution demand professionals with this high level of competence and $40 \%$ of them mentioned that professionals working in their companies have this ability as is required (Table 2).

\section{Ability to acquire new knowledge}

In analyzing this competence, we see how $50 \%$ of EG mentioned that they have this high ability feature; and the same percentage said that this required level of competence in the company is high relative to the ability to acquire new knowledge. Moreover $70 \%$ of EM felt that their organizations require professionals with a high level of this competence and only $50 \%$ of EM mentioned that GR working in their organizations have a high level (Table 2).

\section{Ability to use tools}

With respect to this competence 30\% of GR indicated that their ability to use tools is high; regarding working companies $50 \%$ said that they require professionals who have a high level (Table 2), so graduates are perceived with less level that is required by the labor market.

Table 2. Review of graduates (GR) and employers (EM) on high (A lot or a great deal) of the skills required in the workplace and their weighted average (WA SRW), the skills of the graduate profile and weighted average (WA SGR) and total weighted Average (WA

TOTAL) in the category of knowledge, analytical thinking, reasoning and tools.

\begin{tabular}{|c|c|c|c|c|c|c|c|}
\hline \multirow{3}{*}{ competition } & \multicolumn{3}{|c|}{ Level required at work } & \multicolumn{3}{|c|}{$\begin{array}{l}\text { Level having the graduate } \\
\text { profile }\end{array}$} & \\
\hline & \multicolumn{2}{|c|}{$\begin{array}{l}\text { Percent who think } \\
\text { that the required } \\
\text { level at work is } \\
\text { high }\end{array}$} & \multirow[t]{2}{*}{$\begin{array}{l}\text { WA } \\
\text { SRW }\end{array}$} & \multicolumn{2}{|c|}{$\begin{array}{l}\text { Percent who think } \\
\text { that the graduate } \\
\text { level is high profile }\end{array}$} & \multirow[t]{2}{*}{$\begin{array}{l}\text { WA } \\
\text { SGR }\end{array}$} & \\
\hline & GR & EM & & GR & EM & & $\begin{array}{l}\text { WA } \\
\text { TOTAL }\end{array}$ \\
\hline $\begin{array}{l}\text { Logical mathematical } \\
\text { reasoning ability. }\end{array}$ & 50 & 0 & 15 & 40 & 10 & 19 & 17 \\
\hline $\begin{array}{l}\text { Analytical thinking } \\
\text { ability }\end{array}$ & 50 & 50 & 50 & 20 & 50 & 41 & 46 \\
\hline $\begin{array}{l}\text { Ability to master } \\
\text { knowledge of your area }\end{array}$ & 50 & 50 & 50 & 50 & 50 & 50 & 50 \\
\hline $\begin{array}{l}\text { Ability to master } \\
\text { knowledge of other areas }\end{array}$ & 50 & 50 & 50 & 40 & 40 & 40 & 45 \\
\hline $\begin{array}{l}\text { Ability to rapidly acquire } \\
\text { new knowledge. }\end{array}$ & 50 & 70 & 64 & 50 & 50 & 50 & 57 \\
\hline Ability to use tools. & 50 & 50 & 50 & 30 & 30 & 30 & 40 \\
\hline Average & 50 & 45 & 47 & 38 & 38 & 38 & 42 \\
\hline
\end{tabular}


The results of this table indicate that graduates have career preparation skills in this category of medium to high. It is observed that the competence that mostly contributes to this result is the ability to rapidly acquire new knowledge with $57 \%$.

\section{Innovation}

The economic development of an organization, a country or a society depends on its ability to leverage opportunities presented by exploiting their current resource endowment and adding or developing new resources and / or ideas to materialize value-generating projects (new-applications) as they can take advantage of future opportunities; because with the globalization of markets huge a problems and many task to solve these also emerge. Importantly, these resources and / or ideas become innovations when they are used to meet a specific need and valued by the labor market.

\section{Ability to identify new opportunities}

In this competition, 50\% of GR have revealed that they have a high level and the same percentage said that this capacity is required at high level in they have companies where they work. Meanwhile 50\% of EM say this capability is required heavily in their businesses and $10 \%$ of these mention that GR features with high capacity to detect new opportunities, ie entrepreneurs perceive only some of their personal graduate degrees with high level in competence and therefore this means that the missing of this review, mentions that their hired and graduates of any profession-career staff do not have this competence in high level as required by them (Table 3).

\section{Ability to find new ideas and solutions}

In this capacity we can observe that $40 \%$ of GR indicated that they use high level and $50 \%$ say that this capacity is required at high level in the companies where they work, so the opinion of GR with respect to this competence is to the extent that the labor market high level demands this capability, GR perceived to have this competence in a lowel level than required by the companies where they work. With regards to the opinion of EM, 50\% say that this competence is required at high level and $40 \%$ indicated that professionals working in their organizations have this capability at a low level; (Table 3). 
Table 3. Review of graduates (GR) and employers (EM) on high level (much or largely) the skills required in the workplace and their weighted average (WA SRW), the skills of the graduate profile and weighted average (WA SGR) and total weighted Average (WA TOTAL) in the Innovation category.

\begin{tabular}{|l|l|l|l|l|l|l|l|}
\hline & \multicolumn{3}{|l|}{ Level required at work } & \multicolumn{2}{l|}{$\begin{array}{l}\text { Level having the graduate } \\
\text { profile }\end{array}$} & \\
\cline { 2 - 8 } Competition & $\begin{array}{l}\text { Percent who think } \\
\text { that the required } \\
\text { level at work is } \\
\text { high }\end{array}$ & \multirow{4}{*}{$\begin{array}{l}\text { WA } \\
\text { SRW }\end{array}$} & $\begin{array}{l}\text { Percent who think } \\
\text { that the graduate } \\
\text { level is high } \\
\text { profile }\end{array}$ & WA & SGR & \\
\cline { 2 - 6 } & GR & EM & & GR & EM & & $\begin{array}{l}\text { WA } \\
\text { TOTAL }\end{array}$ \\
\hline $\begin{array}{l}\text { Ability to identify } \\
\text { new opportunities. }\end{array}$ & 50 & 50 & 50 & 50 & 10 & 22 & 36 \\
\hline $\begin{array}{l}\text { Ability to find new } \\
\text { ideas and } \\
\text { solutions. }\end{array}$ & 50 & 50 & 50 & 40 & 40 & 40 & 45 \\
\hline Average & 50 & 50 & 50 & 45 & 25 & 31 & 41 \\
\hline
\end{tabular}

Recall that the changes and innovations in modern society requires higher educational responses to the new needs emerging in the professional context, hoping to get the GR increased efficiency and productivity in the labor market.

\section{Communication}

Communication occurs when two or more people interact, in which interaction express feelings, ideas, questions and so on. It is a daily activity for all people. Communication in personal relationships is important, as well as in organizations. In the workplace, a person interacts with peers, superiors, clients, etc. Similarly, he/she receives data, gives or receives instructions and coordinates work teams. All these tasks and relationships are part of good communication in organizations leading to better results within them.

\section{Ability to communicate in a second language}

In a globalized world it is important to manage a second language. However in the case of Engineering Works and Services, that power did not obtain a high level assessment, but the views were evaluated as low at an intermediate level. So a red alert according to this review arised because the GR are perceived whit less capability in this competence to compete in the globalized workplaces. Meanwhile, whit respect to the opinion of the EM the same situation happens, they do not have a high level competence instead the reviews were assessed as low intermediate (Table 4) level e. 


\section{Ability to draft documents}

$10 \%$ of GR have mentioned that they have a high relative whit respect to this competence; and $50 \%$ said that this required level of competence in the company where they work is high. That is, GR perceive themselves whit less competence to write, than what they believe businesses require. Moreover, $20 \%$ of $\mathrm{EM}$ felt that their organizations require professionals with a high level of competence and only $10 \%$ of EM mentioned that the GR that work in their organizations have a high level in writing documents (Table 4).

\section{Ability to be understood}

In this competition $40 \%$ of GR revealed that they have a high level competence, while 50\% thought that they lack this in the institutions where they work. 50\% of the EM believe that their institution requires professionals with a high level competence and only $40 \%$ of them mentioned that professionals working in their companies have this ability at a high level (Table 4).

\section{Ability to present publicly products, ideas or reports}

As for the opinion of the GR there was not a high level of competence found and whit respect to companies where they work, only $50 \%$ said that this ability is required at a high level. With regard to the opinion of the EM, in the same way they feel that professionals do not have this capability at a high level, but $50 \%$ indicated that they require this competence at work in a high level (Table 4).

Table 4. Opinion of graduates (RG) and employers (EM) on high level (much or largely) the skills required in the workplace and their weighted average (WA SRW), the skills of the graduate profile and weighted average (WA SGR) and total weighted Average (WA

TOTAL) in the category of Communication.

\begin{tabular}{|c|c|c|c|c|c|c|c|}
\hline \multirow{3}{*}{ Competition } & \multicolumn{3}{|c|}{ Level required at work } & \multicolumn{3}{|c|}{ Level having the graduate profile } & \\
\hline & \multicolumn{2}{|c|}{$\begin{array}{l}\text { Percent who think } \\
\text { that the required } \\
\text { level at work is high }\end{array}$} & \multirow{2}{*}{$\begin{array}{l}\text { WA } \\
\text { SRW }\end{array}$} & \multicolumn{2}{|c|}{$\begin{array}{l}\text { Percent who think } \\
\text { that the graduate } \\
\text { level is high profile }\end{array}$} & \multirow{2}{*}{ WA SGR } & \\
\hline & GR & EM & & GR & EM & & $\begin{array}{l}\text { WA } \\
\text { TOTA } \\
\text { L }\end{array}$ \\
\hline $\begin{array}{l}\text { Ability to } \\
\text { communicate in a } \\
\text { second language. }\end{array}$ & 0 & 0 & 0 & 0 & 0 & 0 & 0 \\
\hline $\begin{array}{l}\text { Ability to draft } \\
\text { documents. }\end{array}$ & 50 & 20 & 29 & 10 & 10 & 10 & 20 \\
\hline $\begin{array}{l}\text { Ability to be } \\
\text { understood. }\end{array}$ & 50 & 50 & 50 & 40 & 40 & 40 & 45 \\
\hline $\begin{array}{l}\text { Ability to present } \\
\text { publicly products, } \\
\text { ideas or reports. }\end{array}$ & 50 & 50 & 50 & 0 & 0 & 0 & 25 \\
\hline Average & 38 & 30 & 32 & 13 & 13 & 13 & 22 \\
\hline
\end{tabular}


It is important to learn to understand each other and to function appropriately in social and organizational situations; since this act to establish contact with another individual allows us to transmit information that ultimately granted us improvement in personal relationships.

\section{Coordination}

This is a common responsibility for people with management level, as their goal is to direct staff so that all employees work together harmoniously to achieve business goals in the most efficient manner possible.

\section{Ability to work under pressure}

The opinion of the GR and EM regarding this competence shows the following; $50 \%$ of the GR believe they have a high level of competence and with respect to their companies 50\% mentioned that this capacity is required at a high level. Similarly, $50 \%$ of EM believe that the level required in the work of this competition is high and 50\% of EM say that professionals working in their companies have this capability in great measurement (Table $5)$.

\section{Ability to coordinate activities}

In this competition the GR perceived the same capacity as required by the company where they work; since $50 \%$ of these indicated that the level they have with respect to this competence is so high, it was mentioned that this competence is largely required in their organizations where they work. With regard to the opinion of EM, $50 \%$ of them said that this competence is required at high level and in the same percentage have professionals who manifest this power greatly.

\section{Ability to use time effectively}

In this competence on how the GR is perceived in terms of their level and what the company where they work asks level is greater than the perception of EM. That is 56\% of GR are considered high level in the ability to use time effectively and $44 \%$ say that their companies require this high level competence. With regard to the opinion of MS, 50\% indicated they require this high level of competence in their organizations, but there was no classification as to professionals with this high level competence (Table 5). 
Table 5. Review of graduates (GR) and employers (EM) on high level (much or largely) the skills required in the workplace and their weighted average (WA SRW), the skills of the graduate profile and weighted average (WA SGR) and total weighted Average (WA TOTAL) in the category of Coordination.

\begin{tabular}{|l|l|l|l|l|l|l|l|}
\hline & \multicolumn{3}{|l|}{ Level required at work } & \multicolumn{2}{l|}{$\begin{array}{l}\text { Level having the graduate } \\
\text { profile }\end{array}$} & \\
\cline { 2 - 8 } Competition & $\begin{array}{l}\text { Percent who think } \\
\text { that the required } \\
\text { level at work is } \\
\text { high }\end{array}$ & WA & \multicolumn{3}{l}{$\begin{array}{l}\text { Percent who think } \\
\text { that the graduate } \\
\text { level is high } \\
\text { profile }\end{array}$} & WA & \\
\cline { 2 - 7 } & GR & EM & & GR & EM & & $\begin{array}{l}\text { WA } \\
\text { TOTAL }\end{array}$ \\
\hline $\begin{array}{l}\text { Ability to work } \\
\text { under pressure }\end{array}$ & 50 & 50 & 50 & 50 & 50 & 50 & 50 \\
\hline $\begin{array}{l}\text { Ability to } \\
\text { coordinate } \\
\text { activities. }\end{array}$ & 50 & 50 & 50 & 50 & 50 & 50 & 50 \\
\hline $\begin{array}{l}\text { Ability to use time } \\
\text { effectively. }\end{array}$ & 44 & 50 & 48 & 56 & 0 & 17 & 33 \\
\hline Average & 48 & 50 & 49 & 52 & 33 & 39 & 44 \\
\hline
\end{tabular}

Coordination within an organization will always have inter-personal nature, since the concept is linked to the optimization of the allocation of resources and the achievement of the objectives of the company.

\section{Negotiator}

A good negotiator must have the ability to understand and carry the other party in the most convenient way for both, managing interpersonal relationships in the right way and more conducive. Definitely preparing well before a negotiation is a must, as in be sure of what you are going to negotiate and never lose focus.

\section{Ability to negotiate effectively}

As for the GR they do not have this high level of competence with respect to the organization where they work, 50\% mentioned that they are required a high level in this capacity. That is, the GR are still contemplating less capacity that businesses require. On the other hand, the views of EM differs slightly; since 50\% indicated that this competence is largely required in their companies and in the same way as the GR, there is no classification whit respect to high EM graduates who have this ability (Table 6).

\section{Ability to work in team}

This competence has equality from GR in their profile and in terms of what is required of him. 50\% of GR indicated that they count in great measurement with the ability to work in teams and the same percentage. 
Mentioned that the company where they operate professionally, require this high level competence. Similarly, in the perception of EM it is observed that this depends largely on the ability to work in teams projecting a $50 \%$ likewise $50 \%$ say they have working in their company professionals with this ability at a high level (Table 6).

\section{Willingness to question their own or others ideas}

In this competence, the view of EM state there is no consistency as to what is required in their company and in terms of the profile that has the GR employee in their organization. 50\% say they require this capability in their company and 30\% mentioned, they have professionals with this capability in great measurement. Regarding the GR, they still perceive less capacity than required by enterprises.

Table 6. Opinion graduates (GR) and employers (EM) on high (A lot or a great deal) of the competencies required in the workplace and their weighted average (WA SRW), the skills of the graduate profile and weighted average (WA SGR) and total weighted Average (WA

TOTAL) in the category of the Negotiator.

\begin{tabular}{|l|l|l|l|l|l|l|l|}
\hline \multirow{2}{*}{ Competition } & \multicolumn{3}{|l|}{ Level required at work } & \multicolumn{2}{l|}{$\begin{array}{l}\text { Level having the graduate } \\
\text { profile }\end{array}$} & \\
\cline { 2 - 8 } & $\begin{array}{l}\text { Percent who think } \\
\text { that the required } \\
\text { level at work is } \\
\text { high }\end{array}$ & \multirow{3}{*}{$\begin{array}{l}\text { WA } \\
\text { SRW }\end{array}$} & $\begin{array}{l}\text { Percent who think } \\
\text { that the graduate } \\
\text { level is high profile }\end{array}$ & $\begin{array}{l}\text { WA } \\
\text { SGR }\end{array}$ & \\
\cline { 2 - 6 } & GR & EM & & GR & EM & & $\begin{array}{l}\text { WA } \\
\text { TOTAL }\end{array}$ \\
\hline $\begin{array}{l}\text { Ability to negotiate } \\
\text { effectively. }\end{array}$ & 50 & 50 & 50 & 0 & 0 & 0 & 25 \\
\hline $\begin{array}{l}\text { Ability to work in } \\
\text { team. }\end{array}$ & 50 & 50 & 50 & 50 & 50 & 50 & 50 \\
\hline $\begin{array}{l}\text { Willingness to } \\
\text { question their own } \\
\text { or others ideas. }\end{array}$ & 50 & 50 & 50 & 30 & 30 & 30 & 40 \\
\hline Average & 50 & 50 & 50 & 27 & 27 & 27 & 38 \\
\hline
\end{tabular}

Finally, it is important to note that while there are people with an innate gift for negotiation, these skills can also be learned by attending training courses and practice.

\section{Leadership}

Leadership is a process of interaction between people in which one leads, through personal influence and power, energies, potentials and activities of a group to achieve a common goal to transform both the company and the people who work in it. The leader does not impose its ideas, but convenes and engages others to offer better decisions, obtaining 
with it a wide range of alternatives, however, in risky situations, he is the decision maker.

\section{Ability to mobilize the capacities of others}

In this competence $30 \%$ of GR revealed to have less of this competence than what companies require; and 50\% of EM believe that their institution requires professionals with a high level of this competence and only $30 \%$ of them mentioned that professionals working in their companies have this ability (Table 7).

\section{Ability to assert his authority}

As for this competence, EM insists his company requires a high level of $50 \%$ and the same percentage said that professionals that is responsible have this capability at a high level. As a matter for the opinion of GR in the case of this competence, both in the opinion of GR as in the level required, it is manifested by the same percentage to meet at a high level. Obtaining a weighted average in this competence of 50\% (Table 7).

Table 7. Opinion graduates (GR) and employers (EM) on high (A lot or a great deal) of the competencies required in the workplace and their weighted average (WA SRW), the skills of

the graduate profile and weighted average (PP PEG) and total weighted Average (WA

TOTAL) in the category of Leadership.

\begin{tabular}{|c|c|c|c|c|c|c|c|}
\hline \multirow{3}{*}{ Competition } & \multicolumn{3}{|c|}{ Level required at work } & \multicolumn{3}{|c|}{$\begin{array}{l}\text { Level having the graduate } \\
\text { profile }\end{array}$} & \\
\hline & \multicolumn{2}{|c|}{$\begin{array}{l}\text { Percent who think } \\
\text { that the required } \\
\text { level at work is } \\
\text { high }\end{array}$} & \multirow[t]{2}{*}{$\begin{array}{l}\text { WA } \\
\text { SRW }\end{array}$} & \multicolumn{2}{|c|}{$\begin{array}{l}\text { Percent who think } \\
\text { that the graduate } \\
\text { level is high } \\
\text { profile }\end{array}$} & \multirow[t]{2}{*}{$\begin{array}{l}\text { WA } \\
\text { SGR }\end{array}$} & \\
\hline & GR & EM & & GR & EM & & $\begin{array}{l}\text { WA } \\
\text { TOTAL }\end{array}$ \\
\hline $\begin{array}{l}\text { Ability to mobilize } \\
\text { the capacities of } \\
\text { others. }\end{array}$ & 50 & 50 & 50 & 30 & 30 & 30 & 40 \\
\hline $\begin{array}{l}\text { Ability to assert } \\
\text { his authority. }\end{array}$ & 50 & 50 & 50 & 50 & 50 & 50 & 50 \\
\hline Average & 50 & 50 & 50 & 40 & 40 & 40 & 45 \\
\hline
\end{tabular}

The competent leader is one who has the ability to effectively coordinate and organize their work teams, providing an adequate working environment, guiding and directing others to motivate them and urge them on to reach goals and objectives. Likewise he transcends and gives the example through compliance, ethics and commitment.

\section{Specific skills}

Following is an analysis of specific competences by the Engineering Works and Services educational program. The weighted average was 37\%, 
most of which the graduate profile in both the GR and EM review was less than that required in the workplace. The competence with the highest score was the competence for the cooperative and collaborative work with $50 \%$ overall weighted. As the largest contributor to the low result was the troubleshooting of the field of competence (Table 8).

Table 8 Opinion graduates (GR) and employers (EM) on high level (much or largely) the skills required in the workplace and their weighted average (WA SRW), the skills of the graduate profile and weighted average (WA SER) and total weighted Average (WA TOTAL) on specific skills.

\begin{tabular}{|c|c|c|c|c|c|c|c|}
\hline \multirow{3}{*}{ Competition } & \multicolumn{3}{|c|}{ Level required at work } & \multicolumn{3}{|c|}{$\begin{array}{l}\text { Level having the graduate } \\
\text { profile }\end{array}$} & \\
\hline & \multicolumn{2}{|c|}{$\begin{array}{l}\text { Percent who think } \\
\text { that the required } \\
\text { level at work is } \\
\text { high }\end{array}$} & \multirow[t]{2}{*}{$\begin{array}{l}\text { WA } \\
\text { SRW }\end{array}$} & \multicolumn{2}{|c|}{$\begin{array}{l}\text { Percent who think } \\
\text { that the graduate } \\
\text { level is high } \\
\text { profile }\end{array}$} & \multirow[t]{2}{*}{$\begin{array}{l}\text { WA } \\
\text { SGR }\end{array}$} & \\
\hline & GR & EM & & GR & EM & & $\begin{array}{l}\text { WA } \\
\text { TOTAL }\end{array}$ \\
\hline $\begin{array}{l}\text { For cooperative } \\
\text { and collaborative } \\
\text { work }\end{array}$ & 50 & 50 & 50 & 50 & 50 & 50 & 50 \\
\hline $\begin{array}{l}\text { Assess the } \\
\text { technical, social } \\
\text { and economic } \\
\text { feasibility of the } \\
\text { project based on } \\
\text { ethical criteria of } \\
\text { sustainability }\end{array}$ & 40 & 50 & 47 & 30 & 30 & 30 & 39 \\
\hline $\begin{array}{l}\text { Troubles hooting } \\
\text { purview } \\
\text { Effective design of } \\
\text { projects in the area } \\
\text { of professional } \\
\text { competence }\end{array}$ & 40 & 50 & 47 & 0 & 0 & 0 & 24 \\
\hline & 50 & 50 & 50 & 30 & 30 & 30 & 40 \\
\hline Use of TIC'S & 50 & 50 & 50 & 30 & 30 & 30 & 40 \\
\hline $\begin{array}{l}\text { Provide leadership } \\
\text { with responsibility } \\
\text { for their } \\
\text { professional area } \\
\end{array}$ & 50 & 50 & 50 & 20 & 20 & 20 & 35 \\
\hline $\begin{array}{l}\text { Managing } \\
\text { resources in } \\
\text { organizations }\end{array}$ & 50 & 50 & 50 & 50 & 20 & 29 & 40 \\
\hline Average & 43 & 50 & 48 & 27 & 27 & 27 & 37 \\
\hline
\end{tabular}

\section{The state of competence and suggestions in a curriculum review}

Understanding that competencies are the skills and abilities acquired in the academic development of GR and that will allow you to participate in the professional field meeting the demands or requirements of a particular 
situation; is important to note the different views that show both the GR and EM about what they offer and demand in the labor market.

\section{Knowledge, analytical thinking, reasoning and tools.}

In this category it can be seen how two skills: ability to master knowledge of your area, and ability to acquire new knowledge quickly, require more attention in a period not exceeding nine months. The remaining four races require more attention in a period not exceeding six months. What the TIMAX suggests to get an overall average in this category of $42 \%$ is a curricular reform that is implemented considering the antecedent non grata and urgent attention over a period of 6-9 months. (Table 9).

Table 9: Suggestions for a draft revision, modification or curricular and maximum time in years (TIMAX) to accomplish it in the category of knowledge, analytical thinking, reasoning and tools.

\begin{tabular}{|l|l|l|l|}
\hline Competition & $\begin{array}{l}\text { WA } \\
\text { TOTAL }\end{array}$ & Advice & TIMAX \\
\hline $\begin{array}{l}\text { Logical mathematical } \\
\text { reasoning ability. }\end{array}$ & 17 & $\begin{array}{l}\text { Very poor. Don't accept new revenue. } \\
\text { Start a curricular transformation } \\
\text { considering the "non grata" antecedent. }\end{array}$ & 0.5 years \\
\hline $\begin{array}{l}\text { Analytical thinking } \\
\text { ability. }\end{array}$ & 46 & $\begin{array}{l}\text { Very poor. Don't accept new revenue. } \\
\text { Start a curricular transformation } \\
\text { considering the "non grata" antecedent. }\end{array}$ & 0.5 years \\
\hline $\begin{array}{l}\text { Ability to master } \\
\text { knowledge of your area }\end{array}$ & 50 & $\begin{array}{l}\text { Urgent attention. Poor. Contents very } \\
\text { strong changes: Restructuring the } \\
\text { curriculum and competencies. }\end{array}$ & 0.75 years \\
\hline $\begin{array}{l}\text { Ability to master } \\
\text { knowledge of other } \\
\text { areas. }\end{array}$ & 45 & $\begin{array}{l}\text { Very poor. Don't accept new revenue. } \\
\text { Start a curricular transformation } \\
\text { considering the "non grata" antecedent. }\end{array}$ & 0.5 years \\
\hline $\begin{array}{l}\text { Ability to rapidly acquire } \\
\text { new knowledge. }\end{array}$ & 57 & $\begin{array}{l}\text { Urgent attention. Poor. Contents very } \\
\text { strong changes: Restructuring the } \\
\text { curriculum and competencies. }\end{array}$ & 0.75 years \\
\hline Ability to use tools. & 40 & $\begin{array}{l}\text { Very poor. Don't accept new revenue. } \\
\text { Start a curricular transformation } \\
\text { considering the "non grata" antecedent. }\end{array}$ & 0.5 years \\
\hline
\end{tabular}

\section{Innovation}

This category consists of two skills that the labor market requires future professionals, as they will face a variety of demands in which they have to give solutions. The suggestion offered by TIMAX with the results of the total average of $41 \%$ found in this category, that you should make a curriculum change in a period not exceeding six months (Table 10). 
Table 10: Suggestions for a draft revision, modification or curricular and maximum time in years (TIMAX) to realize it in the category of Innovation.

\begin{tabular}{|l|l|l|l|}
\hline Competition & $\begin{array}{l}\text { WA } \\
\text { TOTAL }\end{array}$ & Advice & TIMAX \\
\hline $\begin{array}{l}\text { Ability to identify new } \\
\text { opportunities. }\end{array}$ & 36 & $\begin{array}{l}\text { Very poor. Don't accept new revenue. } \\
\text { Start a curricular transformation } \\
\text { considering the "non grata" antecedent. }\end{array}$ & 0.5 years \\
\hline $\begin{array}{l}\text { Ability to find new ideas } \\
\text { and solutions. }\end{array}$ & 45 & $\begin{array}{l}\text { Very poor. Don't accept new revenue. } \\
\text { Start a curricular transformation } \\
\text { considering the "non grata" antecedent. }\end{array}$ & 0.5 years \\
\hline
\end{tabular}

\section{Communication}

This category is composed of four competences that when emphasized each of them we find a strong alert in the ability to communicate in a second language by obtaining a total weighted average of $0 \%$ therefore TIMAX qualifies this competition as non grata and suggests starting a curriculum change in a time not exceeding six months. The same applies to other tasks, which also suggests strong changes in a time not exceeding six months. The average in this category is $22 \%$ indicating that reaction response to the improved skills that constitute this category must be in a short time (Table 11).

Table 11 Suggestions for a draft revision, modification or curricular and maximum time in years (TIMAX) to realize it in the category of Communication.

\begin{tabular}{|l|l|l|l|}
\hline Competition & $\begin{array}{l}\text { WA } \\
\text { TOTAL }\end{array}$ & Advice & TIMAX \\
\hline $\begin{array}{l}\text { Ability to communicate in a } \\
\text { second language. }\end{array}$ & 0 & $\begin{array}{l}\text { Very poor. Don't accept new } \\
\text { revenue. Start a curricular } \\
\text { transformation considering the "non } \\
\text { grata" antecedent. }\end{array}$ & 0.5 years \\
\hline Ability to draft documents. & 20 & $\begin{array}{l}\text { Very poor. Don't accept new } \\
\text { revenue. Start a curricular } \\
\text { transformation considering the "non } \\
\text { grata" antecedent. }\end{array}$ & 0.5 years \\
\hline Ability to be understood. & 45 & $\begin{array}{l}\text { Very poor. Don't accept new } \\
\text { revenue. Start a curricular } \\
\text { transformation considering the "non } \\
\text { grata" antecedent. }\end{array}$ & 0.5 years \\
\hline $\begin{array}{l}\text { Ability to present publicly } \\
\text { products, ideas or reports. }\end{array}$ & 25 & $\begin{array}{l}\text { Very poor. Don't accept new } \\
\text { revenue. Start a curricular } \\
\text { transformation considering the "non } \\
\text { grata" antecedent. }\end{array}$ & 0.5 years \\
\hline
\end{tabular}




\section{Coordination}

In this category usually TIMAX suggests a history with urgent attentions in two unpleasant contests, demanding curricular and skills needed in a time of 6-9 months. (Table 12).

Table 12 Suggestions for a draft revision, modification or curricular and maximum time in years (TIMAX) to realize it in the category of Coordination.

\begin{tabular}{|l|l|l|l|}
\hline Competition & $\begin{array}{l}\text { WA } \\
\text { TOTAL }\end{array}$ & Advice & TIMAX \\
\hline $\begin{array}{l}\text { Ability to work under } \\
\text { pressure }\end{array}$ & 50 & $\begin{array}{l}\text { Urgent attention. Poor. Contents very } \\
\text { strong changes: Restructuring the } \\
\text { curriculum and competencies. }\end{array}$ & 0.75 years \\
\hline $\begin{array}{l}\text { Ability to coordinate } \\
\text { activities. }\end{array}$ & 50 & $\begin{array}{l}\text { Urgent attention. Poor. Contents very } \\
\text { strong changes: Restructuring the } \\
\text { curriculum and competencies. }\end{array}$ & 0.75 years \\
\hline $\begin{array}{l}\text { Ability to use time } \\
\text { effectively. }\end{array}$ & 33 & $\begin{array}{l}\text { Very poor. Don't accept new revenue. } \\
\text { Start a curricular transformation } \\
\text { considering the "non grata" antecedent. }\end{array}$ & 0.5 years \\
\hline
\end{tabular}

\section{Negotiator}

The skills found in this category are very important in GR due to acquiring these skills they will be better prepared to compete in today's global workplace; because people who have demonstrated this skill will be able to establish relationships and create an atmosphere of trust obtaining better results in the professional field. By getting an overall average of 38\% in this category TIMAX suggests that changes should be carried out in a time of 6-9 months. (Table 13).

Table 13: Suggestions for a draft revision, modification or curricular and maximum time in years (TIMAX) to realize it in the category of The Negotiator.

\begin{tabular}{|l|l|l|l|}
\hline Competition & $\begin{array}{l}\text { WA } \\
\text { TOTAL }\end{array}$ & Advice & TIMAX \\
\hline $\begin{array}{l}\text { Ability to negotiate } \\
\text { effectively. }\end{array}$ & 25 & $\begin{array}{l}\text { Very poor. Don't accept new } \\
\text { revenue. Start a curricular } \\
\text { transformation considering the "non } \\
\text { grata" antecedent. }\end{array}$ & 0.5 years \\
\hline Ability to work in team. & 50 & $\begin{array}{l}\text { Urgent attention. Poor. Contents very } \\
\text { strong changes: Restructuring the } \\
\text { curriculum and competencies. }\end{array}$ & 0.75 years \\
\hline $\begin{array}{l}\text { Willingness to question their } \\
\text { own or others ideas. }\end{array}$ & 40 & $\begin{array}{l}\text { Very poor. Don't accept new } \\
\text { revenue. Start a curricular } \\
\text { transformation considering the "non } \\
\text { grata" antecedent. }\end{array}$ & 0.5 years \\
\hline
\end{tabular}

\section{Leadership}

This category includes two competences which are the ability to mobilize the capacities of others that received a total weighted average of $40 \%$, and the ability to assert their authority with a $50 \%$, according to 
TIMAX there should have more attention and begin a transformation curricular considering the antecedent "urgent Care" and "Non pleasing" in a maximum period of 6-9 months. (Table 14).

Table 14 Suggestions for a draft revision, modification or curricular and maximum time in years (TIMAX) to realize it in the category of Leadership.

\begin{tabular}{|l|l|l|l|}
\hline Competition & $\begin{array}{l}\text { WA } \\
\text { TOTAL }\end{array}$ & Advice & TIMAX \\
\hline $\begin{array}{l}\text { Ability to mobilize the } \\
\text { capacities of others. }\end{array}$ & 40 & $\begin{array}{l}\text { Very poor. Don't accept new } \\
\text { revenue. Start a curricular } \\
\text { transformation considering the "non } \\
\text { grata" antecedent. }\end{array}$ & 0.5 years \\
\hline $\begin{array}{l}\text { Ability to assert his } \\
\text { authority. }\end{array}$ & 50 & $\begin{array}{l}\text { Urgent attention. Poor. Contents very } \\
\text { strong changes: Restructuring the } \\
\text { curriculum and competencies. }\end{array}$ & 0.75 years \\
\hline
\end{tabular}

\section{Specific skills}

Table 15 presents the results of the specific competences studied, a total weighted average of $37 \%$ was obtained, indicating that all competencies, and according to TIMAX, should have more attention and should initiate curriculum changes considering the antecedent "urgent Care" and "Non pleasure" of this competence in a period of 6-9 months.

Table 15 Suggestions for a draft revision, modification or curricular and maximum time in years (TIMAX) to realize it on specific skills.

\begin{tabular}{|l|l|l|l|}
\hline Competition & $\begin{array}{l}\text { WA } \\
\text { TOTAL }\end{array}$ & Advice & TIMAX \\
\hline $\begin{array}{l}\text { For cooperative and } \\
\text { collaborative work }\end{array}$ & 50 & $\begin{array}{l}\text { Urgent attention. Poor. Contents very } \\
\text { strong changes: Restructuring the } \\
\text { curriculum and competencies. }\end{array}$ & 0.75 years \\
\hline $\begin{array}{l}\text { Assess the technical, social and } \\
\text { economic feasibility of the } \\
\text { project based on ethical criteria } \\
\text { of sustainability }\end{array}$ & 39 & $\begin{array}{l}\text { Very poor. Don't accept new revenue. } \\
\text { Start a curricular transformation } \\
\text { considering the "non grata" antecedent. }\end{array}$ & 0.5 years \\
\hline $\begin{array}{l}\text { Troubleshooting purview } \\
\text { Effective design of projects in } \\
\text { the area of professional } \\
\text { competence }\end{array}$ & 40 & $\begin{array}{l}\text { Very poor. Don't accept new revenue. } \\
\text { Start a curricular transformation } \\
\text { considering the "non grata" antecedent. }\end{array}$ & 0.5 years \\
\hline $\begin{array}{l}\text { Use of TIC'S } \\
\text { Very poor. Don't accept new revenue. } \\
\text { Start a curricular transformation } \\
\text { considering the "non grata" antecedent. }\end{array}$ & 0.5 years \\
\hline $\begin{array}{l}\text { Provide leadership with } \\
\text { responsibility for their } \\
\text { professional area }\end{array}$ & 35 & $\begin{array}{l}\text { Very poor. Don't accept new revenue. } \\
\text { Start a curricular transformation } \\
\text { considering the "non grata" antecedent. }\end{array}$ & 0.5 years \\
\hline $\begin{array}{l}\text { Managing resources in } \\
\text { organizations }\end{array}$ & 40 & $\begin{array}{l}\text { Very poor. Don't accept new revenue. } \\
\text { Start a curricular transformation } \\
\text { considering the "non grata" antecedent. }\end{array}$ & 0.5 years \\
\hline
\end{tabular}




\section{Conclusions}

The study of graduates and employers is very important, as field research allows us to find out the current situation and the professional performance of its graduates, their personal needs and requirements of professionals in the workplace; well as evaluating the curricular relevance of educational programs and possible adjustments. This information is extremely useful in guiding the training of new professionals and designing academic programs that strengthen and promote continuous improvement strategies in academia, permitting with this to understand and meet the labor demand. Therefore the follow-up study of graduates and employers becomes a key strategy for self-knowledge and improvement of HEI.

Both the competency analysis model and TIMAX model are endless successive approximation processes seeking quality and improvement in academic, only that comparing the two models you find that the competency analysis covers the generic skills with a 35\% of jurisdiction in red, interpreting that all these require immediate review. While TIMAX counting with a more difficult grade when calculating the weighted average of the opinions of the GRW and flush immediately marks the priority that must be addressed by the competition degree of difficulty; i.e., the first model marks the same equivalence of care (red) to the powers which are determined by TIMAX that allows different attention span of 6 months. The same applies to the specific, $71 \%$ scored red, resulting in immediate need of revision; therefore TIMAX points out his attention on a period not exceeding six months.

\section{References:}

ANUIES (1998). Core Scheme for Graduates Studies. National Association of Universities and Institutions of Higher Education. Mexico, D.F.

AQU (2009) .www.aqu.cat / aqu_catalunya / historia_es.html. Retrieved October 15, 2009.

Casas Rius, JR, Jofre Roca, L., Samitier Oliveras, J., Saiz Arniz, A., Sarramona López, J., Grifoll Saurí, J., et al. (2008 12 15). www.enqa.eu/files/InformeAQU_CUCSUR_ang.pdf. Retrieved January 13, 2010.

CUCSUR. (2010). Follow-up Study of Graduates and Employers Survey. Engineering Works and Services. Autlan de Navarro, Jalisco.

Diaz B. A. (2000). Employers university. A study of their opinions. CESUMiguel Angel Porrua, Mexico.

Ada G. Gómez, Z. Mendoza and Edith P. Alfredo Castañeda (2010). Study for the opening of technical courses in the College of Science and Technology Studies of the State of Jalisco, CECYTEJ. Case: 12 Cranbrook 
Campus. Thesis MAGRE CUCSUR U of G. Autlan de Navarro, Jalisco., Mexico. pp. 103-105.

Gutiérrez, H. (2005). Random Sampling. Total quality and productivity, p. 337-339, Editorial Mc Graw Hill. Mexico.

José F. López Gómez and Juan P. Montanes, "How the employers' view is obtained" in Methods of analysis of the employment of university, the University Coordination Council, Secretary of Publications and Audiovisual Media, Madrid, 2003.

Malhotra, Naresh K. (2004). Market research. An applied approach, pp. 278300, Prentice Hall. Mexico.

Navarro Leal, Aurelio, "Theoretical considerations for the study of graduates" in Basic scheme for graduates studies, ANUIES, Mexico, 1998. McMillan, J. H., \& Schumacher, S. (2005). Educational research. Mexico: Pearson. 